\title{
The Association between Cerebrospinal Fluid Open Pressure and Body Mass Index in Idiopathic Intracranial Hypertension
}

\author{
Hasanain A. Al-Khalidi ${ }^{1}$ D, Shehab A. Goloom², Mohammed Radhi Radeef ${ }^{1}$, Ahmed Muhi Fahad $^{3 *}$ (D) \\ ${ }^{1}$ Department of Internal Medicine, Faculty of Medicine, University of Kufa, Al-Najaf, Iraq; ${ }^{2}$ Department of Surgery, Middle \\ Euphrates Neurosciences Center, Al-Najaf Health Directorate, Ministry of Health, Al-Najaf, Iraq; ${ }^{3}$ Department of Cardiothoracic \\ and Vascular Surgery, Al-Sadder Teaching Medical City, Al-Najaf Health Directorate, Ministry of Health, Al-Najaf, Iraq
}

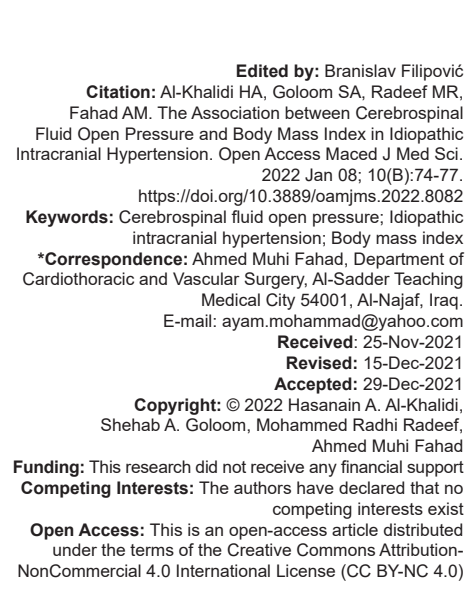

Abstract

BACKGROUND: Idiopathic intracranial hypertension $(\mathrm{IIH})$ is strongly associated with obesity. However, the relationship between cerebrospinal fluid open pressure (CSFOP) and body mass index (BMI) is still controversial.

AIM: The aim of this study is to assess the relationship between CSFOP and BMI in patients with IIH.

METHODS: The measurement of CSFOP was done by Lumbar puncture manometry following a standardized procedure. Age and gender were registered and BMI was calculated for each patient.

RESULTS: This study enrolled 104 patients with $\mathrm{IIH}, 96$ females and eight males, with mean age was $31.88 \pm 13.73$ years. The mean CSFOP was $410.48 \pm 129.98 \mathrm{~mm} \mathrm{H}{ }_{2} \mathrm{O}$ and the mean BMI was $33.97 \pm 53 \mathrm{~kg} / \mathrm{m}^{2}$ There was a significant positive relationship between the CSFOP and BMI $(p=0.0001)$ according to the Pearson correlation test. There was no relationship between the age $(p=0.06)$, gender $(p=0.16)$ and CSFOP of the patients. CONCLUSIONS: The CSFOP was positively correlated with high BMI of the patient. There was no relationship between patients demographic features and CSFOP.

\section{Introduction}

Idiopathic intracranial hypertension $(\mathrm{IIH})$ is defined as high intracranial pressure in the absence of any identifiable cerebrospinal fluid (CSF); meningeal, brain parenchymal, or cerebral vascular pathology; and diagnosed by using modified Dandy criteria [1]. $\mathrm{IIH}$ affects young, overweight women with childbearing age [2], [3]. Furthermore, $90 \%$ of females with IIH have a body mass index (BMI) of more than $30 \mathrm{~kg} / \mathrm{m}^{2}$ [4], the risk of IIH is further associated with rapid increase in body weight even when these occur below the threshold of obesity [5]. The scarcity of full knowledge about the variation in limit of cerebrospinal fluid open pressure (CSFOP) may lead to a false impression of pathologically increased intracranial pressure, and resulting in unnecessary investigations in addition to fear and anxiety for the patient. The International Headache Society (IHS) defines increased CSFOP as more than $250 \mathrm{~mm} \mathrm{H}_{2} \mathrm{O}$ in adults or unsedated, non-obese children and more than $280 \mathrm{~mm} \mathrm{H} 2 \mathrm{O}$ for the obese children, in International Classification of Headache Disorders, $3^{\text {rd }}$ edition, 2018 [6]. The limits of normal CSFOP have been revised in the last decades, and it was previously considered $200 \mathrm{~mm} \mathrm{H} 2 \mathrm{O}$ was the normal upper limit in the IHS Classification, $2^{\text {nd }}$ edition, 2004 [7].

This study aimed to assess the association between BMI and CSFOP in the Iraqi patients diagnosed with $\mathrm{IIH}$.

\section{Materials and Methods}

\section{Study Design and Setting}

A cross-section study enrolled (104) Iraqi patients diagnosed with $\mathrm{IIH}$ by a consultant neurologist, conducted in the Middle Euphrates Neuroscience Center in Al-Najaf City, Iraq, from the first of September 2019 to the first of September 2020.

\section{Data Collection}

Full data regarding the patients age, gender, height, weight with BMI has been recorded. The patients were divided into five age groups; between 
7 and 19 years, between 20 and 29 years, between 30 and 39 years, between 40 and 49 years, and above 50 years. The BMI was measured by dividing the weight in kilograms by the square of the height in meters. Moreover, the patients were divided into six BMl groups; BMI <18.5, BMI between 18.5 and 24.9, BMI between 25 and 29.9, BMI between 30 and 34.9, BMI between 35 and 39.9, and BMI over 40 [8]. All patients were diagnosed with IIH if they met the modified Dandy criteria (except CSF opening pressure of more than $250 \mathrm{~mm} \mathrm{H}_{2} \mathrm{O}$ during lumbar puncture [LP]), which include signs and symptoms of increased intracranial pressure, no localizing neurologic sign except sixth cranial nerve palsies, normal neuroimaging finding, with normal constituents of CSF, and no other cause.

\section{Assessment}

Each patient participating in this study undergone full work-up for a possible medical and neurological disease, and LP for CSF analyses was considered part of this work-up, including a measurement of the CSF opening pressure (CSFOP), cells, protein and glucose contents. Full medical history was obtained to exclude any patient who had other diseases, or who had taken antibiotics, vitamins, or other drugs, that causing intracranial hypertension. Moreover, no treatment for the intracranial hypertension had been given before the investigations. The patients were included without regard to gender, age, or clinical symptoms. This procedure done within a few days after consultation, therefore, the patients were rarely in acute distress or anxiety. All patients had been examined with brain computed tomography scans, brain magnetic resonance imaging with magnetic resonance venography prior to LP, in order to exclude a possible expansive lesion or venous sinus thrombosis and for radiological signs of raised intracranial pressure.

\section{Procedure}

LPs was performed at our neurology department, following the standard procedure of the department; the patient positioned relaxed on the left lateral side, hips slightly flexed, use of spinal needle 20 -gauge or 22-gauge with local anesthesia (3 mg/kg), and the opening pressure was recorded in the lateral decubitus position at the beginning of the procedure by using a single-use plastic manometer held at the same needle level and waiting to reach steady-state.

\section{Scientific and ethical approval}

Scientific approval for the study was granted from the Scientific Department in the Middle Euphrates Neuroscience Center in Al-Najaf City, Iraq (No. 4402 in July 2019).

\section{Statistical analysis}

The statistical analysis was done using SPSS version 20. Continuous variables were expressed as mean \pm SD while categorical variables were expressed as frequencies and percentages. Post-Hoc test was used to compare the CSFOP among BMI and age groups. Pearson correlation and scattered plot were used for testing correlation between CSFOP, age, and BMI. $p<0.05$ was considered significant.

\section{Results}

In this study, we enrolled 104 patients: 96 were female $(92.3 \%), 8$ were male $(7.7 \%)$, their mean age was $31.88 \pm 13.73$ years (range $7-92$ years), the mean CSFOP was $410.48 \pm 129.98 \mathrm{~mm} \mathrm{H} 2 \mathrm{O}$ (range 190-740 $\mathrm{mm} \mathrm{H}_{2} \mathrm{O}$ ). The mean BMI was $33.97 \pm 53 \mathrm{~kg} / \mathrm{m}^{2}$ (range $22.04-47.03 \mathrm{~kg} /$ $\left.\mathrm{m}^{2}\right) ; 10(9.6 \%)$ had a normal weight (BMl 18.5-24.9 kg/ $\left.\mathrm{m}^{2}\right), 22(21.2 \%)$ were overweight (BMI $\left.25.0-29.9 \mathrm{~kg} / \mathrm{m}^{2}\right)$, $26(25 \%)$ were obese I (BMI 30.0-34.9 kg/m²), $24(23.1 \%)$ were obese II (BMI 35.0-39.9 kg/m ${ }^{2}$ ) and 22 (21.2\%) were obese III (BMI $\geq 40.0 \mathrm{~kg} / \mathrm{m}^{2}$ ). The demographic data and baseline clinical characteristics (Table 1).

Table 1: Demographic data and baseline characteristics of the patients

\begin{tabular}{lll}
\hline Variable & $\mathrm{n}$ & $\%$ \\
\hline Age group (years) $(31.88 \pm 13.74)$ & 10 & \\
$7-19$ & 42 & 9.6 \\
$20-29$ & 32 & 30.4 \\
$30-39$ & 10 & 30.8 \\
$40-49$ & 10 & 9.6 \\
$50+$ & & \\
Sex & 96 & 92.3 \\
Female & 8 & 7.7 \\
Male & 10 & 9.6 \\
BMI $\left(\mathrm{kg} / \mathrm{m}^{2}\right)(33.97 \pm 6.53)$ & 22 & 21.2 \\
Normal & 26 & 25 \\
Overweight & 24 & 23.1 \\
Obese I & 22 & 21.2 \\
$\quad$ Obese II & & \\
Obese III & & \\
\hline BMI: Body mass index. & &
\end{tabular}

In this study, there was a significant positive relationship between the CSFOP and BMI ( $p=0.0001)$ according to the Pearson correlation test as shown in Figure 1. There was no relationship between age and $\operatorname{CSFOP}(p=0.06)$ as illustrated in Figure 2.

Moreover, those with age group 40-49 years had a significant higher mean CSFOP than other age groups ( $p=0.002$ ), according to the Post-Hoc test. There was no relationship between sex and CSFOP $(p=0.16)$. Moreover, there was a significant difference in mean CSFOP according to BMI groups and the obese III was the highest $(p=0.003)$, according to Post-hoc test (Table 2). 


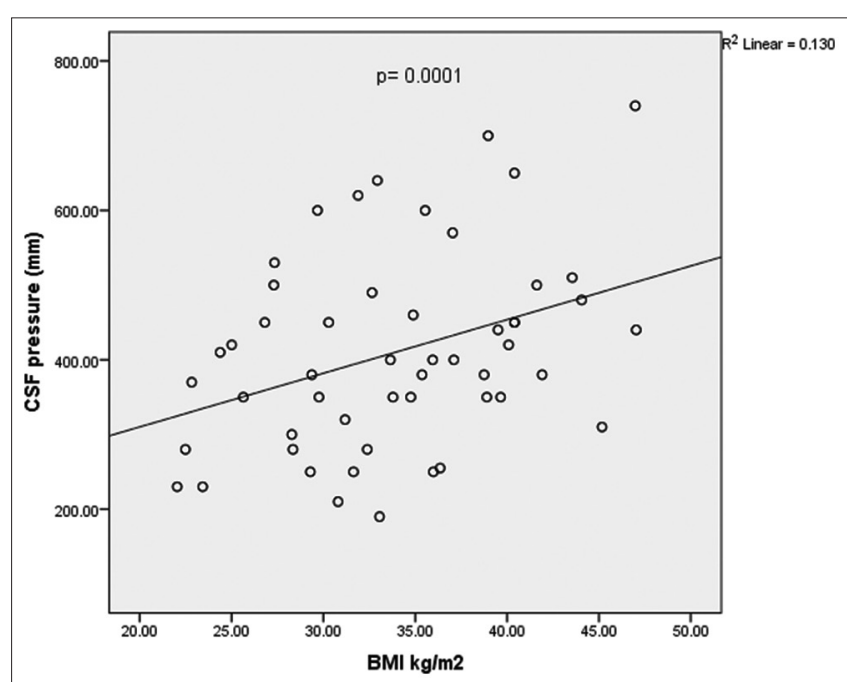

Figure 1: Correlation between body mass index and cerebrospinal fluid open pressure

\section{Discussion}

This study is conducted in the Middle Euphrates Neurosciences Center in Al-Najaf City in Iraq, to assess the relationship between CSFOP and BMI in patients with $\mathrm{IIH}$. The ranges of CSFOP in healthy individuals were 100-250 $\mathrm{mm} \mathrm{H}_{2} \mathrm{O}$ [9].

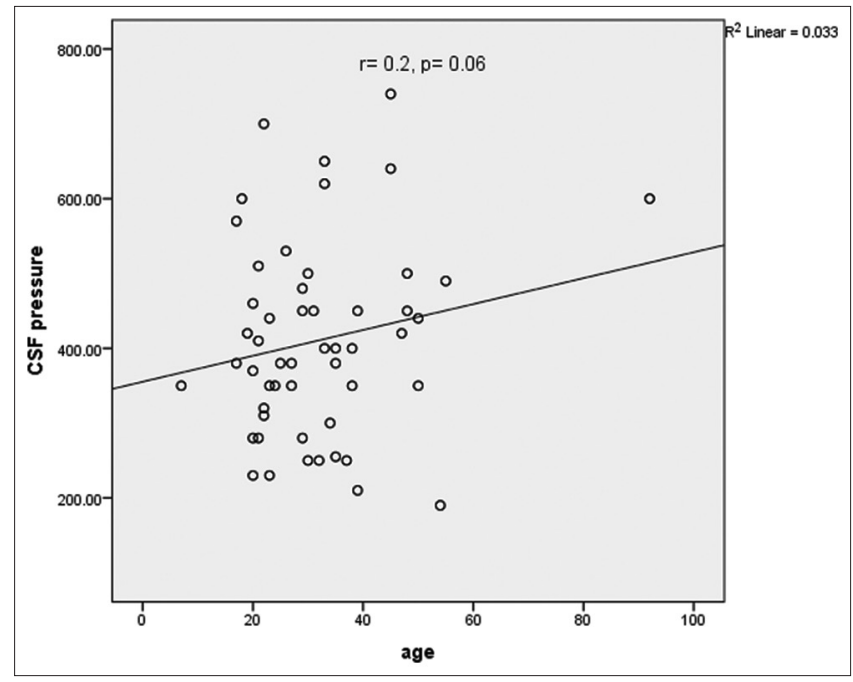

Figure 2: Correlation between age and cerebrospinal fluid open pressure

The relationship between CSFOP and BMI of the patient is still controversial. In this study, CSFOP has no correlation with the age and sex of the patient, and this finding was not compatible with Norway study by $B \varnothing$ and Lundqvist [10], which demonstrate that the CSFOP has a significant relationship with the age and sex of the patient, and this may be due to small sample size in our study with the majority of them were female. Moreover, a few numbers of those patients with extreme age groups.
Table 2: Comparison of the mean CSFOP according to demographic variables

\begin{tabular}{llll}
\hline Variable & $\mathrm{n}$ & $\begin{array}{l}\text { CSF pressure } \\
\left(\mathrm{mm} \mathrm{H}_{2} \mathrm{O}\right) \text { Mean } \pm \mathrm{SD}\end{array}$ & $\begin{array}{l}\text { Post-hoc test } \\
\text { P value }\end{array}$ \\
\hline Age & & & \\
$7-19$ & 10 & $464 \pm 107.21$ & 0.056 \\
$20-29$ & 42 & $385.24 \pm 111.16$ & 0.06 \\
$30-39$ & 32 & $382.2 \pm 129.1$ & 0.01 \\
$40-49$ & 10 & $550 \pm 127.9$ & 0.002 \\
$>50$ & 10 & $414 \pm 145.54$ & 0.055 \\
Sex & & & \\
Male & 8 & $472.5 \pm 112.2$ & 0.16 \\
Female & 96 & $405.3 \pm 130.54$ & \\
BMI & & & \\
Normal & 10 & $304 \pm 77.63$ & 0.01 \\
$\quad$ Overweight & 22 & $400.9 \pm 107.83$ & 0.05 \\
$\quad$ Obese I & 26 & $385.38 \pm 140.26$ & 0.01 \\
$\quad$ Obese II & 24 & $422.9 \pm 133.03$ & 0.04 \\
$\quad$ Obese III & 22 & $484.54 \pm 116.89$ & 0.003 \\
\hline CSFOP: Cerebrospinal fluid open pressure, BMI: Body mass index. &
\end{tabular}

There was a significant positive correlation between CSFOP and BMI and this finding was compatible with many studies done worldwide. Norway study by $\mathrm{B} \varnothing$ and Lundqvist [10], showed that the BMI, age, and gender all independently affected CSFOP. Wakerley et al. [11], reported that $\mathrm{BMI}$ and body fat percentage both positively correlated with the CSFOP, but BMI was more predictive in female and body fat percentage was more predictive in male. Subramaniam and Fletcher [12], mentioned the risk of developing $\mathrm{IIH}$ and associated visual loss increase with higher BMI. Kilgore et al. [13], said that the incidence of IIH had increased since 1990, and this was highly correlated with increase in obesity during the same period. This study was incompatible with [14], [15]. Ardissino et al., reported that the high BMI beyond the threshold of obesity did not independently rise the risk of $\mathrm{IIH} \mathrm{[14].} \mathrm{Kim} \mathrm{et} \mathrm{al.,} \mathrm{documented} \mathrm{that}$ the obesity was infrequently found in Caucasians with $\mathrm{IIH}$ and suggested that obesity has no a major role in the pathogenesis of $\mathrm{IIH}$ in Asian patients [15]. An intraabdominal, visceral, distribution of fat may be a common sign connect IIH both to PCOS (androgen excess) in women and to hypogonadism (androgen deficiency) in men [16]. Fat distribution and the hormonal influences that modify and accompany it may be as important as total adiposity in the pathogenesis of $\mathrm{IIH}$. Its influence is of emerging interest [17], [18], [19].

\section{Conclusions}

From this study, we conclude CSFOP was positively correlated with high BMI of the patient. Moreover, patients in the obese III group had the highest CSFOP.

\section{Limitation of the study}

The study limitation including small sample size of patients with the majority of them were female. Moreover, a few numbers of those patients with extreme age groups. 


\section{Acknowledgments}

The authors would like to thank Dr. Ahmed Salih Alshewered for their helping.

\section{References}

1. Friedman DI, Liu GT, Digre KB. Revised diagnostic criteria for the pseudotumor cerebri syndrome in adults and children. Neurology. 2013;81(13):1159-65. https://doi.org/10.1212/ WNL.0b013e3182a55f17

PMid:23966248

2. Degnan AJ, Levy LM. Pseudotumor cerebri: Brief review of clinical syndrome and imaging findings. AJNR Am J Neuroradiol. 2011;32(11):1986-93. https://doi.org/10.3174/ajnr.A2404 PMid:21680652

3. Ogden CL, Carroll MD, Kit BK, Flegal KM. Prevalence of childhood and adult obesity in the United States, 2011-2012. JAMA. 2014;311(8):806-14. https://doi.org/10.1001/jama.2014.732

\section{PMid:24570244}

4. Hornby C, Mollan SP, Botfield H, O'Reilly MW, Sinclair AJ Metabolic concepts in idiopathic intracranial hypertension and their potential for therapeutic intervention. J Neuroophthalmol. 2018;38(4):522-30. https://doi.org/10.1097/ WNO.0000000000000684

PMid:29985799

5. Daniels AB, Liu GT, Volpe NJ, Galetta SL, Moster ML, Newman NJ, et al. Profiles of obesity, weight gain, and quality of life in idiopathic intracranial hypertension (Pseudotumor cerebri). Am J Ophthalmol. 2007;143(4):635-41. https://doi. org/10.1016/j.ajo.2006.12.040

PMid:17386271

6. Headache Classification Committee of the International Headache Society. The International Classification of Headache Disorders $3^{\text {rd }}$ ed., Vol. 38. Cephalalgia: Headache Classification Committee of the International Headache Society; 2018. p. 1-211

7. Headache Classification Committee of the International Headache Society. The International Classification of Headache Disorders. $2^{\text {nd }}$ ed., Vol. 24. Cephalalgia: Headache Classification Committee of the International Headache Society; 2004. p. 9-160.

8. Klein S, Wadden T, Sugerman HJ. AGA technical review on obesity. Gastroenterology. 2002;123(3):882-932. https://doi. org/10.1053/gast.2002.35514

PMid:12198715

9. Whiteley W, Al-Shahi R, Warlow CP, Zeidler M, Lueck CJ. CSF opening pressure: Reference interval and the effect of body mass index. Neurology. 2006;67(9):1690-1. https://doi. org/10.1212/01.wnl.0000242704.60275.e9

PMid:17101909

10. Bo SH, Lundqvist C. Cerebrospinal fluid opening pressure in clinical practice a prospective study. J Neurol. 2020;267(12):3696701. https://doi.org/10.1007/s00415-020-10075-3

PMid:32681283

11. Wakerley BR, Warner R, Cole M, Stone K, Foy C, Sittampalam M. Cerebrospinal fluid opening pressure: The effect of body mass index and body composition. Clin Neurol Neurosurg. 2020;188:105597. https://doi.org/10.1016/j.clineuro.2019.105597 PMid:31778875

12. Subramaniam S, Fletcher WA. Obesity and weight loss in idiopathic intracranial hypertension: A narrative review. J Neuroophthalmol. 2017;37(2):197-205. https://doi. org/10.1097/WNO.0000000000000448

\section{PMid:27636748}

13. Kilgore KP, Lee MS, Leavitt JA, Mokri B, Hodge DO, Frank RD, et al Re-evaluating the incidence of idiopathic intracranial hypertension in an era of increasing obesity. Ophthalmology. 2017;124(5):697700. https://doi.org/10.1016/j.ophtha.2017.01.006 PMid:28187976

14. Ardissino M, Moussa O, TangA, Muttoni E, Ziprin P, PurkayasthaS Idiopathic intracranial hypertension in the British population with obesity. Acta Neurochir (Wien). 2019;161(2):239-46. https://doi. org/10.1007/s00701-018-3772-9 PMid:30564882

15. Kim TW, Choung HK, Khwarg SI, Hwang JM, Yang HJ. Obesity may not be a risk factor for idiopathic intracranial hypertension in Asians. Eur J Neurol. 2008;15(8):876-9. https://doi. org/10.1111/j.1468-1331.2008.02207.x PMid:18684312

16. Glueck CJ, Aregawi D, Goldenberg N, Golnick KC, Sieve L, Wang P. Idiopathic intracranial hypertension, polycysticovary syndrome, and thrombophilia. J Lab Clin Med. 2005;145(2):72-82. https://doi.org/10.1016/j.lab.2004.09.011 PMid:15746649

17. Glueck CJ, lyengar S, Goldenberg N, Smith LS, Wang P. Idiopathic intracranial hypertension: Associations with coagulation disorders and polycystic-ovary syndrome. J Lab Clin Med. 2003;142(1):3545. https://doi.org/10.1016/S0022-2143(03)00069-6 PMid:12878984

18. Ooi LY, Walker BR, Bodkin PA, Whittle IR. Idiopathic intracrania hypertension: Can studies of obesity provide the key to understanding pathogenesis?BrJNeurosurg.2008;22(2):187-94. https://doi.org/10.1080/02688690701827340 PMid:18348012

19. Wozniak SE, Gee LL, Wachtel MS, Frezza EE. Adipose tissue: The new endocrine organ? A review article. Dig Dis Sci Epub. 2009;54(9):1847-56. https://doi.org/10.1007/s10620-008-0585-3 PMid:19052866 